\title{
The Place of Traditional Art Forms as a Positive Element in The Inculcation of Culture in The Nigerian Youth
}

\author{
Talatu Onkala Adiwu (PhD), Hamsatu Saleh (PhD), and Bello Usman Amsami (PhD) \\ Department of Fine Arts, Faculty of Environmental Studies University of Maiduguri Borno State-Nigeria \\ *Corresponding Author's Email: adiwutalatuonkala@gmail.com
}

\begin{abstract}
Nigerian cultures and traditions are demonstrated mainly through art, but in modern times, culture seems to have departed from its usual traditional form and given way to technology. This can be seen in the youth who consistently try to bring new ways of life or rather try very hard to imitate the western system of life. Many Nigerian youths appear to be shunning conventional methods of pursuing their passion and making credible marks in the plethora of areas available to them; but remain focused on the fast-changing stream of contemporary climes thus, diverting their creative talents outward instead of inward. The aim of this argument is to establish the need for positive inculcation of cultural and traditional values in Nigerian youths through the exposition of available traditional arts. The paper focuses on establishing the place and role of traditional artforms as a positive element for the inculcation of cultural values in the Nigerian youth of today. It posits that, every Nigerian youth has the potential to come up with novel ideas and innovations that can be used to build a strong platform for self-discovery and the creation of newer avenues for leadership. The article also looks at how traditional artforms can change attitudes, bring about new ideas and notions for the forward and progressive development of the country through the younger generation.
\end{abstract}

Key words: Youths, Arts, Culture, Traditional, Inculcation

DOI: $10.7176 / \mathrm{ADS} / 94-05$

Publication date:August $31^{\text {st }} 2021$

\section{Introduction}

One of the basic functions of art is its suitability in enhancing expression as well as its capability to diversify communication systems. This means that, art combines the dual role of speaking and transmission. The plethora of forms that art exists in makes both its aforementioned characters an exciting experience. Art mainly shows itself predominantly in culture; in fact, the earliest forms of recorded art expressions were in essence depictions of cultural activities engaged in by the early man. Such activities depicted were both agrarian and domestic in nature, yet they were represented in such an ethereal manner that they elevated the position of such daily and now considered mundane activities to an almost spiritual state/level. What this establishes is the familial relationship that has and will continue to exist between art and culture. These two herculean concepts seem to enhance the existence of each other. Where art preserves culture, culture provides art with an outlet.

Since culture is also significantly about humans, and how their lives are lived; it comes to bear that humans, being an expressive specie must direct their experiences and values through forms that they deem fit for such occurrences. This is most suitably done through art. Culture is alternatively defined as "the arts and other manifestations of human intellectual achievement regarded collectively" (oxforddictionaries.com). Following the aforementioned definition, it is clear that art and culture embody the vivid images of a people's way of life combined with historical elements of the past, present and at times the future. One of the major aspects of art that increases its viability to humanity is that it draws significantly from the folk heritage of regions. Just as cultures evolve, so also the art forms that accompany it.

Art, dance, literature, folklore, music, and body art/design are all examples of Nigerian culture and in contemporary times it has included western versions such as painting, sculpture, performance and many others. This is not to infer that prior to the colonisation of Nigeria that these artforms did not exist; contrary to that fact is that all these forms did exist and evidence abound of this rich repository of art forms. What the aforementioned postulation infers is that, prior to colonisation, these artforms were identified as different objects serving a largely aesthetic and religious/ritualistic function. As a result, most Nigerian civilizations classify art forms based on the tasks they perform for their societies. Where the function was largely ritualistic these were termed or looked as sacred objects not to be trifled with but objects to be worshipped and revered. In areas where art objects are meant for entertainment, they are adored, admired and cautiously taken care of by the practitioners of such activities. Instances where art objects were used as part of domestic activities these were carefully 
maintained and ensured that they served for a long time and were often passed down to the younger generations as family heirlooms.

This exposition endeavours to establish categorically, that art is a viable tool for the inculcation of culture amongst the younger generation. It aims to establish the relationship of art with culture, the state of the Nigerian youth and proffer suggestions on how art can be used to effectively and gainfully engage the Nigerian youth. It presents art as a useful tool for the dissemination of culture and its characters as well as provide examples where specific art forms have been used for cultural indoctrination.

\section{Connection between Nigerian Arts and Culture}

Okafor (2018) is of the opinion that, human beings use art and cultural practices to communicate their feelings and values. Nigerian art and culture encapsulate the vibrant picture of the Nigerian way of life, as well as the beautiful history of the country. One of the most important elements of Nigerian art and culture is that it draws influence from the region's traditional folk history (https://www.legit.ng/1101506-nigerian-traditional-artculture.html).

The story of the beginning and creative development of arts intersection with culture in Nigeria is as old as humanity itself. No one can clearly state that this is the exact moment that art began to find form in culture nor van it be established categorically when culture began to be embodied by or in art. This means that the two have always coexisted in a symbiotic relationship. Njoku (n.d) explains that, "the story of art and culture could simply be put as the story of civilization and the evolution of man".

Thus, the majority of the resources and clues used by ethnographers and anthropologists to recreate the history of primitive humans are centered on cultural artifacts and tools left behind by early humans. To understand the art and culture of the modern political entity known as Nigeria, one must first get familiar with the inhabitants who make up Nigeria and their cultural origins before attempting to make sense of their ethnic fabric prior to their colonisation by the British. This is believed to have been the start of formal and historic documentation of the heterogeneous people. It is inferred here that this was mainly done to ensure that an effective, purposeful and central system of governance was established by the British (affinityart.gallery.com).

Consequently, the amalgamation of the protectorates into one began to be considered as an important aspect of any study or exposition on Nigeria's art and cultural development. As previously said, Nigerian culture and traditions are predominantly expressed through their art forms, which include dance and literature in the form of proverbs, folktales, and music. Others include sculpture, painting, and all sorts of crafts, like pottery, weaving, and tie and dye.

Njoku continues his foray into traditional Nigerian art and cultures by indicating that almost if not all of the ethnic groups of people that constitute the country Nigeria have and still practice one or more forms of art as a significant aspect of their traditions and way of life. As initially indicated, art, religion and culture in all African societies cannot be separated from all aspects of life. This is also true to Nigeria, art is inseparable from religion and vice versa. Art in traditional Nigerian society is seen as an avenue for religious expression; it is a voice and carrier of all religions and the conduit through which worshippers' worship.

Before the advent of the colonial masters to Nigeria, the country or geographical location now known as Nigeria was a haven for artistic explorations of all kinds. Since the people practiced traditional religion without any constraints and hinderances. Nigerians created their art to translate their world as they saw it, as they interacted with it, as well as a means to visualize their "cosmological views on life and esoteric ideas. They employed art in various cultural celebrations and ceremonies special commemorations because of the Pantheist nature of the traditional religion" (Njoku, n.d).

Nigerian societies' great collection of ancient images and deities were created (see fig. I below) and spirit entities which were embodiments of all-wind, fire, water and land are examples of natural phenomena and components. They used art objects such as masks, dolls, totems, wall decorations, sculptures made out of various materials their immediate environment provided them with to give recognition to such deities as "possessing spiritual authority and required reverence" (Akpowowo, 2010). The creation of these objects was not accidental nor was it practical but it was a conscious creation of art pieces meant to embody the essence and characteristics of the forces they believed in. Apart from being personifications of spirits, the creation of art was also a means of subduing or at least pacifying the deities, and in some cases, harnessing their power in order to bring them 
under some form of control or enter into a kind of alliance that would or might be regarded advantageous to both parties, albeit one mortal and the other spirit/immortal. The magical interpretations ascribed to the cave paintings unearthed in Lascaux, France, are similar to this tradition.

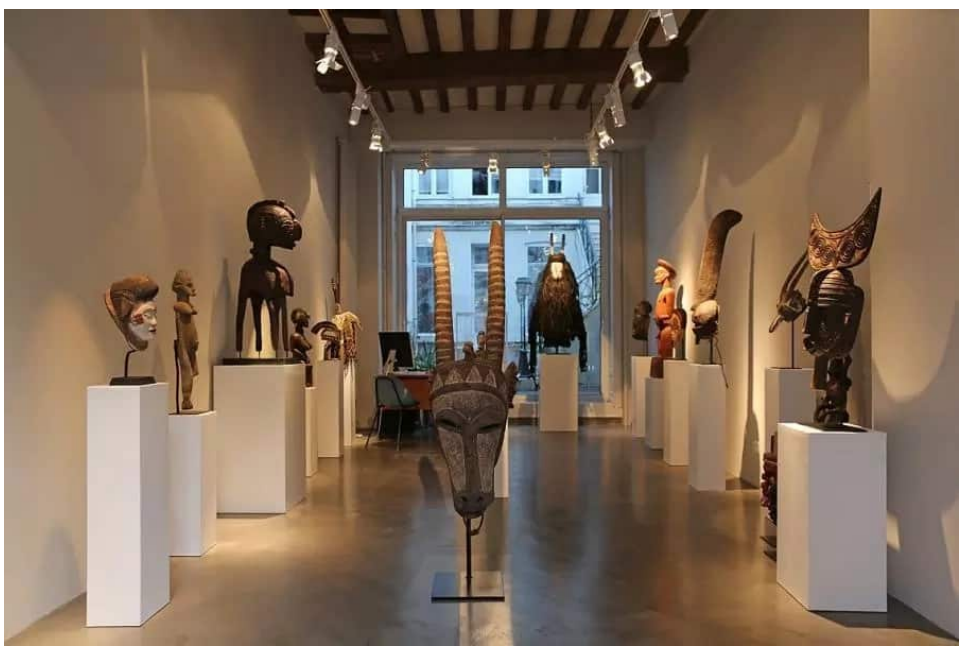

Figure I, Cross section of traditional art objects on display, Date: $n . d$, Source: (https://www.legit.ng/1101506-nigerian-traditional-art-culture.html).

Therefore, for the purpose of context within the confines of this article, it is considered important to establish a general overview of traditional Nigerian art through a review of the most common artistic media utilized in "major artistic flashpoints" in Nigeria (Egwali, 2016). These "flashpoints" are enumerated and discussed in no particular order as is usually obtainable. The main objective of this section is to elaborate summarily "the major cultural groups with the most extant collection of traditional works of art" (Egwali, 2016). Njoku indicates thus:

A close study of the traditional art in Nigeria, shows that most of the artifacts and cultural pieces produced by the different cultural groups are largely grouped within the boundaries of these mediums: Stones, Terracotta, Woods, Bronze, Paintings and Crafts. (https://affinityart.gallery/nigerian-art-a-short-history/).

\section{Esie and Ikom Monoliths/Stone Sculptures:}

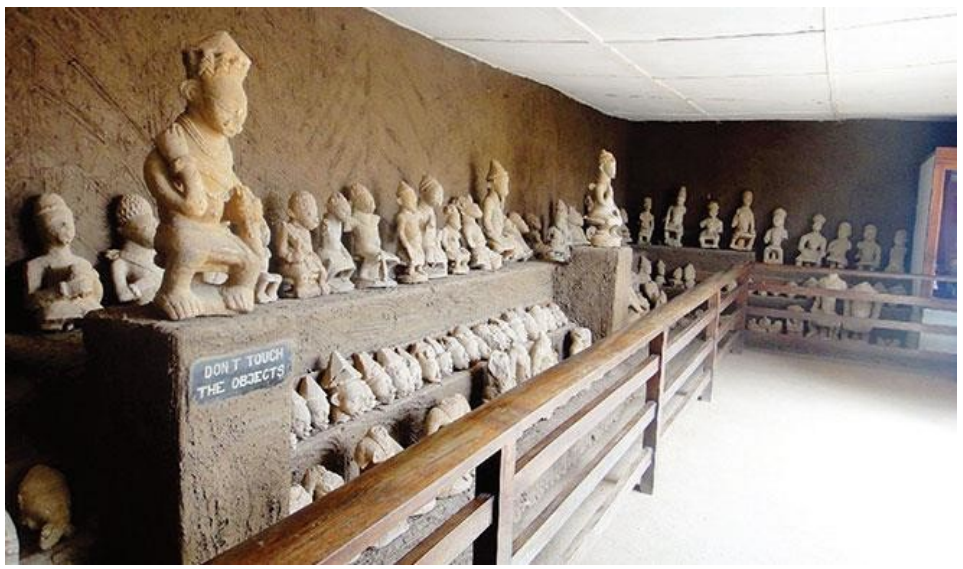

Fig. II, Esie Soapstone Carvings (Era Esie), 1775,

Source: http://www.kwarareporters.com/2018/08/the-esie-stone-image-ere-esie-who.html 
One of the frequently asked questions about the Esie stone carvings is who made them? Despite the fact that Esie is primarily a Yoruba community, the origin and identity of the stone sculptors have remained a mystery, crystallizing into many mythological stories by the society (See fig II above). As a result, ethnographers, anthropologists, and archeologists have made significant efforts in several directions to interpret the works in order to unravel the riddle surrounding their identity.

The stone sculptures depict a cosmopolitan mix of cultures, with elements such as elegant hairstyles, costumes, tribal markings, neck pieces, and bracelets, as well as diverse cultural traits that link them to several ethnicities in the vicinity. The portrayal of the stone carvings suggests to these scholars that, the carvings' underpinning goal was likely a pictorial archiving of the people's living tradition by the creator. The intricacies documented in the garment forms, tribal marks, and hairstyles help to paint a more complete picture of life before technological advances.

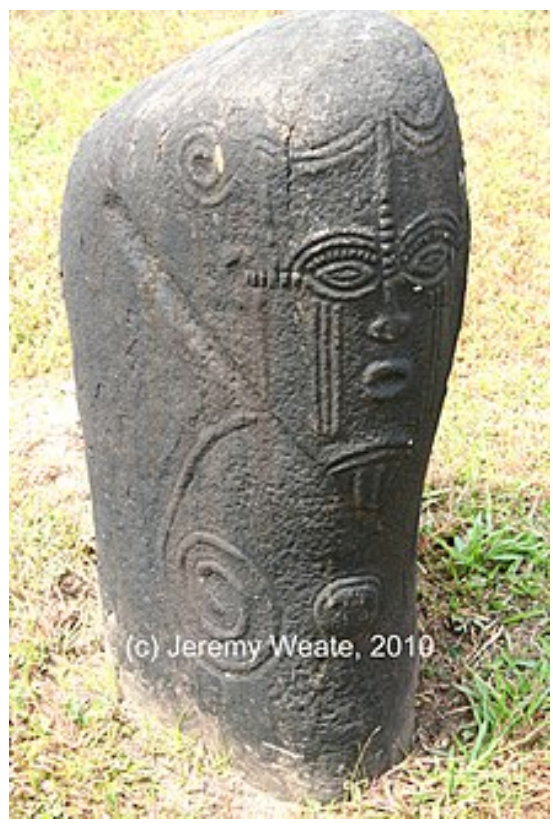

Fig. III, Ikom Stone Monolith, Date: Unknown, Source: en.wikipedia.org

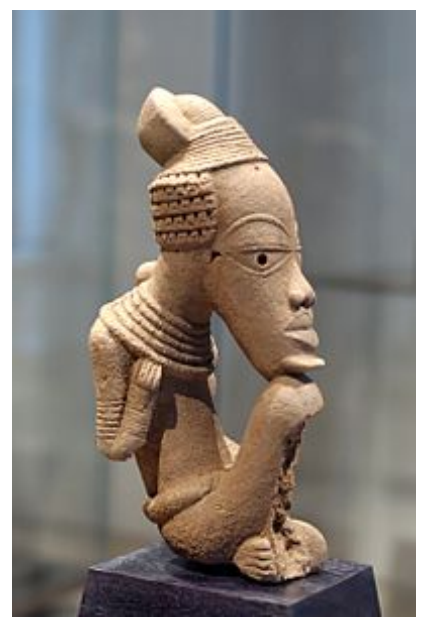

Fig. IV, Nok Terracotta Sculpture, Louvre, 2000BC - 300AD, Source: en.wikipedia.org 


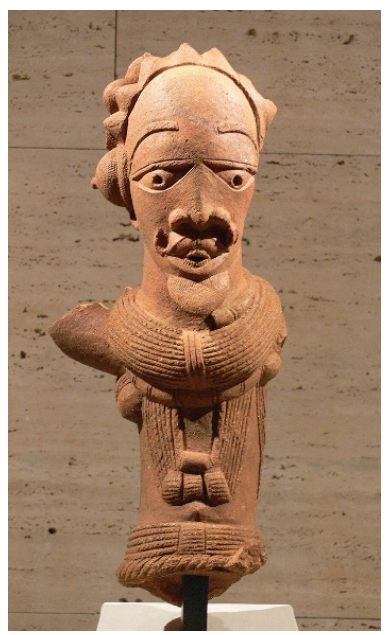

Fig. V, Nok male figure; 500 BC-500 AD; terracotta; $49.5 \times 22.2 \times 16.8 \mathrm{~cm}(19.4 \times 8.7 \times 6.6$ in $)$; from northern Nigeria; Kimbell Art Museum (Fort Worth, Texas, USA)

Terracotta Culture: Nearly every single ethnic group in Nigeria has some sort of terracotta art, and most sections of the country, particularly in the south, have some form of sculptural tradition. However, when one travels to the north of the country, the picture begins to change. The Nok culture thrived between 2000BC and 300AD, making it the earliest known form of traditional art not only in Nigeria but also throughout West Africa. The foregoing are its characteristics: Intricate hairstyles, spherical heads, pierced eyes, nose, mouth, and ears, semi-circular and triangular eyes and lids, and so on.

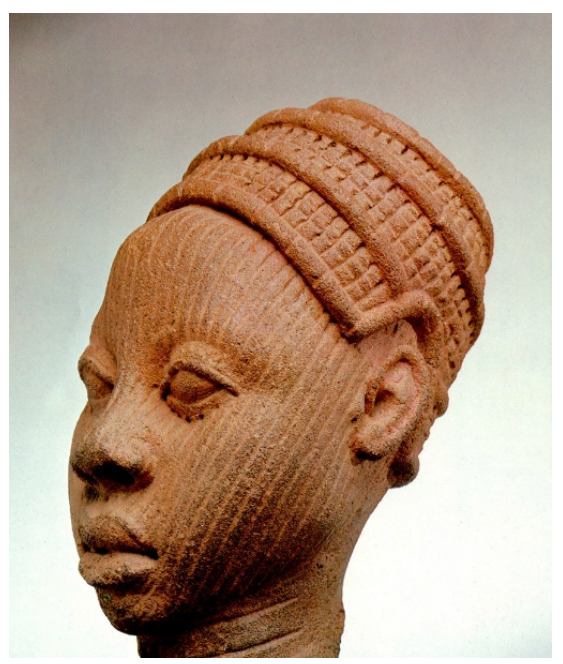

Fig VI, Ife Terracotta Head, Clay, H. 16 cm (6 1/4"), National Museum, Lagos, Nigeria, 79.R.6 (Ife 305), Photo by Dirk Bakker

Apart from Nok culture, Ife-terracotta works are also another important ancient traditional art form in South Western Nigeria. Ife art, which dates from the 12 th to 15 th centuries A.D., is at the center of Yoruba lineage. 


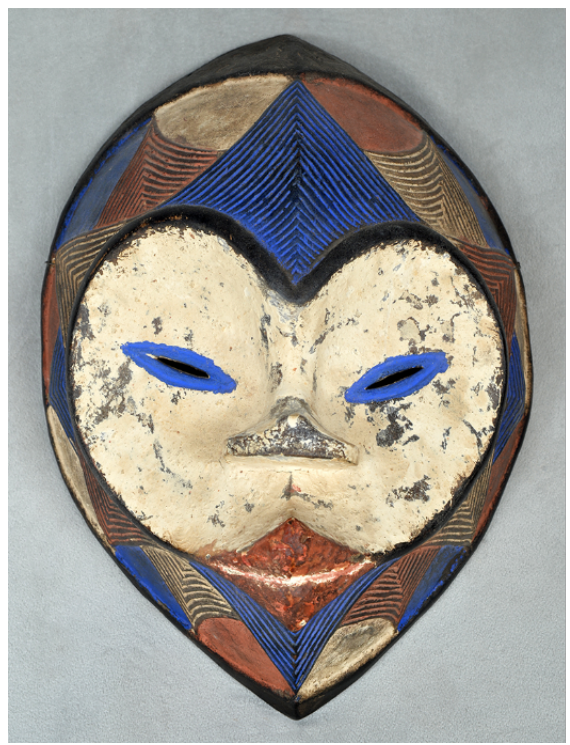

Fig. VII, Ibibio Ekpo Mask, Wood, Kaolin and Pigment, 1900s, Source: maskmusuem.org

\section{Wood Carvings}

Nigeria is home to a large number of sculptural works. The majority of these pieces of art are made of wood and have a variety of applications. This was also conceivable because of the country's cultural diversity and, most notably, because of the abundant availability of timber facilitated by the country's positioning within Africa's tropical rainforest region. As a result, practically every cultural group in Nigeria has a distinct wood carving heritage with distinct techniques and traits. Nigeria and parts of Benin are home to the Ibibio. The Eket are an Ibibio subgroup recognized for their relatively sophisticated visual style. Through the ritual invocation of the Ekpo jungle spirit, the society uses masks to defend and purify the community. Women are not allowed to contact the dancers during masked dances for the cleansing and safeguarding of the village, and women are prohibited from joining the society. Higher-ranking membership in the Society necessitates a significant amount of income and confers great social prestige.

\section{Ancestral figures}

In Nigeria, numerous ethnicities have a practice of carving ancestor figures, including Ibeji images in Yoruba country. In Yoruba custom, these statues are made to commemorate the birthing or passing of twin(s). People believe that twins are formidable spirits capable of providing wealth to their families or causing calamity to anyone who doesn't honour them. Ikenga wood carvings are one of the most popular and prominent ancestral figures among the Igbos of South-Eastern Nigeria. 


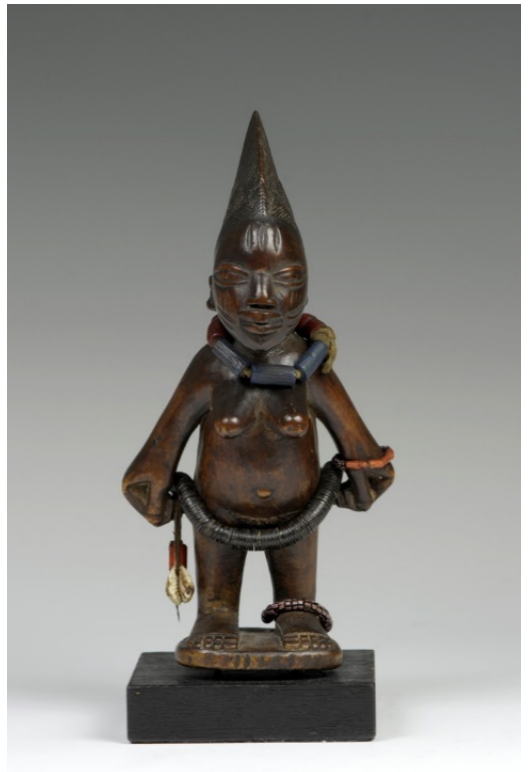

Fig. VIII, Ere Ibeji (twin figure), Wood, beads, H. $20 \mathrm{~cm}(8 ")$, University of Iowa Stanley Museum of Art, The Stanley Collection of African Art, X1986.489

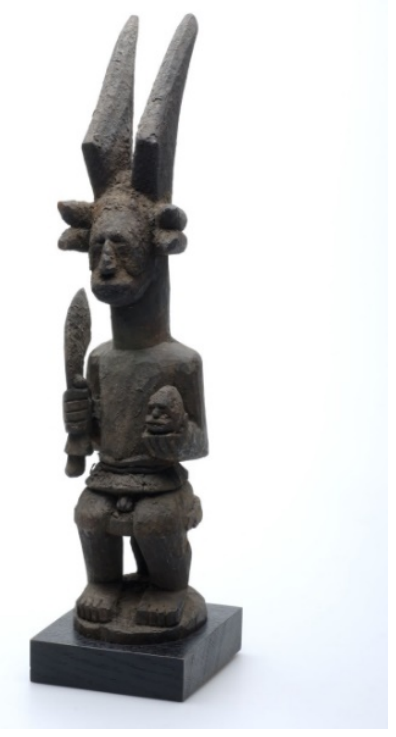

Fig. IX, Ikenga figure, wood, Source: en.wikipedia.org

Following Nigeria's independence, artistic foraging has flourished, ranging from traditional conventions to the blooming of a diverse range of current trends in art output. The Nigerian art scene is now more individualistic, detribalized, and universal as a result of formal Western education and gaining inspiration from culturally rich elements, with popular conventional elements remaining visible in the body of works identified now as modern Nigerian Art.

Influences from globalization, as well as present cultural, social and political challenges, have resulted in a proliferation of methods and techniques. Nonetheless, the status of art in Nigeria is in constant motion and remains dynamic, bringing up new avenues for creative expression in a world awash with a diverse range of media and genres. 


\section{The State of the Nigerian Youth and Inculcation through Traditional Nigerian Arts/Culture}

The present condition of the Nigerian youth is a very complex one. With rising costs of living and persistent insecurity, the Nigerian youth faces many challenges on the way to establishing his or herself. None the less, the youth is still expected to rise to the occasion and make the most of the situation. Aliyu (2017) opines that, youths in Nigeria are expected to play a unique role in the society, particularly in the arts but reverse seems to be the case, he further notes that the youth in society find themselves at odds hence, the general disregard towards the innate abilities that the majority possess. This is because the youth face a lot of challenges which lead to situations that involve dropping out of school, street hawking, life as domestic servants, juvenile delinquency and many other unsavoury acts.

Arabome (2016) extends the thought process of Aliyu ibid by indicating that youths in Nigeria are very creative but need to make ample use of the situations around them instead of focusing on external migration. Obi (2015), on the other hand, believes that Nigerian youths are a critical component of any social evolution, as well as any geopolitical entity's human and material resources. Therefore, no serious government can afford to disregard or completely overlook the youth, who are the future foundation. Obi contends that the youth (18-35 years) have not received a fair deal in most policy initiatives, particularly in Nigeria; instead, they have been neglected, marginalized, discriminated against, and even victimised in diverse ways that present a risk to national security, stability, and long-term advancement, and should not be treated with any further levity.

Though the government seems to be making strides in providing the youth with employment and other benefits, the larger portion of youth development in Nigeria still lacks adequate and organised management and or responsibility. These points are not farfetched as it is evident in the large numbers of unoccupied youths roaming the streets of the nation brandishing themselves as potential catalyst for either meaningful sustainable development or as undesirable elements to the society. Due to the continuous and dynamic nature of the challenges the youths face, some have become resourceful by being creative thereby giving them the chance to deviate from a seeming foreboding future.

Inculcation is the process of imparting knowledge, wisdom, or values in someone through repetition. Inculcation is the practice of imparting or impressing ideas on someone. To inculcate is to instill or influence an idea on someone. Inculcation is a sort of instruction in its most basic form. Atuma (2017) has emphasized the importance of parents instilling traditional cultural values in their children in attempt to uphold the culture and encourage continuity and unity. Atuma points out that unless parents take responsibility for instilling their culture's correct values and standards in their children, the next generation may regard culture and all of its accessories as outdated, fetishistic, or just irrelevant to their modern way of life. This aversion to culture and its elements could be a result of the Nigerian youth's growing proclivity for western ethos, which the authors of this research see as a by-product of the nation's earlier indifference for youth research and growth.

Okogba (2018) posits that, Nigerian youths have reached a desperate point in history where every available tool is needed to be utilized to restore sanity as well as its lost glory. This assertion was made at the Culture Institute Children's Cultural Extravaganza held in 2018, at the National Theatre, Iganmu Lagos-Nigeria. The cultural extravaganza's target was the correcting of current trends in terms of the total neglect of the traditional arts and culture by the younger generation. Driven by a wholesome assimilation of foreign culture resulting in the upsurge of behaviours inimical to our existence as a people. The aim of the cultural extravaganza was to infuse positive Nigerian cultural values in the youths through the arts. The acting Executive Secretary National Institute for Cultural Orientation (NICO), Mr Louis Eriomala said that the program was organized to hold annually:

"to demonstrate our appreciation of the strategic importance of children in the promotion and presentation of our cultural heritage, and that it is designed to inculcate in children our cherished cultural values of honesty, hard work, tolerance, patriotism, respect for elders and for the sanity of human life".

The guest speaker Mrs Victoria Agodo an educationist further tasked "parents on the need to intensify efforts towards ensuring that, children are given proper cultural foundation stressing that culture from the cradle should be encouraged". This has become a major issue found among the youths which needs to be corrected.

Muraino and Ugwumba (2014) both assert that, moral decadence is behaving in a way that displays low moral standards. It also means gross reduction in the moral standard and values within the society. While on the other hand Adebisi (2018) observes that, the behaviour of the youth is not only because of the negative societal influence, but also because of the failure to implement some family values especially at the youths' formative 
years. These family values have and are underappreciated in their position as the primary and foundational roles of inculcating socio-cultural values into the child at an early stage. Adebisi continues the narrative by stating that, traditional African people taught their young ones to be morally upright by devising effective and pragmatic ways of impacting certain ideas and virtues in them in order to mould them for leadership position for the future right from home. This practice seems to have taken a back sit in contemporary society hence the increase in personal and societal neglect of the youth.

Art is a way of life, it's a way of expression, and it has always been rooted in culture because it connects people of a culture to their past and also brings in new ideas and insight. In modern times, culture seems to have departed from traditional ways to new movements, this can be seen in our youth who try to bring in new ways of life or rather try to imitate the western culture. Because the world is changing so quickly, many Nigerian youths are eschewing traditional means of pursuing their own passion and creating significant contributions in a variety of fields. Nigerian teenagers have been diverting from their cultural values to their own innovative ideas.

Aderemi (2018) said that a gradual initiative is taking its root in the mind of the Nigerian youth. Every young Nigerian will always want to come out with something new, different and will always hope for a better change. There needs to a change in the mindset of the Nigerian youth. They must believe that they can build a strong platform for self-discovery and create new avenues for leadership. Though their ideas may have positive effect, but it is gradually deviating from the norms and values of culture.

\section{Sustenance of Culture through Art forms/Education}

Despite the fact that migration and globalization is so rampant across the world, acculturation has been another problem affecting human society. But the following measures will help minimize the effect and sustain culture of society from time to time.

- Art programmes should be funded to service art activities through schools and museums. A national evaluation of the youth arts development found that there are significant effects on participants concerning art knowledge and communication. Art activities can improve the attitudes and behaviours of young people (Clawson and Coolbaugh, 2001).

- Museums should be funded and maintained with superficial care. As museums keep cultural materials that educate the younger ones pertaining their culture and ancestors.

- Constant Home Town Visitation should be done by parents. The constant visitation will educate the younger ones to be familiar with their culture.

- Art Council should support the traditional artists (blacksmith, weavers, leather workers, sculptors, woodcarvers and bronze casters) to keep producing artefacts.

\section{Culture and Inculcation in Human Society}

Culture as defined by several scholars and cultural anthropologist is a way of life. Every human society has societal values, attitudes, standards, aspiration beliefs and taboos. Every member aspires to meet these codes and ethic for him or her to gain recognition in the societal cycle. As a result, children from various cultures receive varied inputs from their surroundings. This explanation allowed for a wide range of cultural variances in the beliefs and behaviors of youngsters. Parents in many cultures play a significant impact in shaping their children's behaviour and thought patterns. The way a youngster engages socially is also influenced by the cultural differences in interactions between adults and children (Huang, 2009).

According to Ahanonu (2015), culture can be used to increase a country's revenue base. Among other things, cultural assets could be leveraged to improve the country's image. This is also due to the fact that the country's values constitute the people's way of life, necessitating the adoption of culture's good aspects. He believes that embracing the country's cultural past will create national unity and empathy through encouraging multiculturalism. He implies that Nigerian youngsters should acquire our forefathers' traditions a little more than a means of contributing to the country's cultural growth, as the country's youth are becoming more westernized and disregarding moral norms and values. Skills transfer and community development should be viewed as critical tools for youth participation and must not be overlooked. As a result, the youth must be engaged in the preservation of the county's traditions because it is a form of knowledge transfer from one era to the next.

In support of Huang (2009), Bagshaw (2009) adds, "...culture is significant in that it offers a sense of belonging, connection, and context," all of which are proven to be critical for the growth of young people. Considering this, 
Bagshaw contends that if more than one culture coexists in a geographic region, issues can occur. She recognised two issues that can arise and have an impact on a given perception: acculturation and assimilation.

\section{Acculturation}

This is a scenario that arises through repeated first-hand encounter between two separate groups. This is a greater-scale transmission of cultural materials over a larger territory.

\section{Assimilation}

This occurs on the minority group's side. The minority loses almost all of its culture's behaviors and ideals. Young individuals who immigrate to a new nation with their families frequently switch back and forth between two cultures or feel alienated from their ethnic group.

Acculturation and assimilation are all components of today's Nigerian society, where millennials are increasingly stubborn when it comes to traditional and cultural values. The schooling system, particularly the creative program, is one of the best means to assure continual incorporation of cultures and beliefs.

\section{Conclusion}

Art has always been intertwined with a society's customs and heritage. Being recognized as a component that brings people together by providing information about the past, as well as insights into the future, and a source of clarity in the present. Culture has broadened over time to embrace neighbouring communities, resulting in greater diversity in human experience. This has also aided in the remaking of ordinary life systems, the improvement of conceptions, and the expansion of creative domains. The purpose of this study was to examine how culture and tradition can be used to positively influence younger generations. It has examined a number of existing traditional Nigerian forms of art in order to demonstrate how the country's rich culture may be used to promote youth development. It demonstrates the necessity for kids to be schooled in accordance with their cultures, and to be taught how to not only appreciate but also utilize the rich culture with which they have been endowed for their own benefit. Nigerian cultures play a vital role in society by strengthening the country's identity, self-reliance, confidence, and entrepreneurial approach.

\section{References}

Adebisi K. S (2018). Moral Decadence Among Nigerian Youths as Future Leaders: A Sociocultural Regeneration. ASSRJ. Advances in Social Sciences Research Journal. Vol 5, No 2. (2018) > Adebisi DOI: http://dx.doi.org/10.14738/assrj.52.3179

Aderemi K. (2018). At Economic Summit, Nigerian Youths Seek Real Change. Retrieved 6/3/2019 from www.sunnewsonline.com/at-economic-summit-nigerian-youth-seek-real-change/

Ahanonu N. (2015). Our cultural heritage has positive sides. Retrieved 6/3/2019 from www.vanguardngr.com/2015/01/cultural-heritage-positive-sides-executive-director/

Aliyu M. (2017). Youth Unemployment and Visual Arts. MAJASS (Maiduguri Journal of Arts and Social Sciences). Special Edition. Arts and Design Vol 14 2017. Pp 83.

Arabome A, (2016) 'Rising Unemployment, a National Security Risk' in the Guardian Published by Guardian Newspaper Limited Rutam House, Lagos vol.32, no 13,619 pp.27 and 28.

Atuma U. (2017). Adenuga urges parents to inculcate cultural values in children.

Retrieved:4/3/2019from https://www.google.com/search?ei=b.inculcating + of + culture + in + the + nigerian + youth $+\&$ oq $=$ inculcating + of + culture + in + the + nigerian + youth $+\& g s$ _ $1=$ mobile-gws-wiz-serp

Akpowowo, B. (2010). Traditional Contemporary Visual Arts in Nigeria. Knowledge Review, Volume 21 No. 1 Bagshaw, S. (2009) Culture and Youth Development, www.researchgate.net.

Egwali, F. (2016). Ancient and Contemporary Benin Bronze-Differences and Similarities: The Content, Context and the Journey so Far. IDEA-Studia nad strucktura I rozwojem pojec filozoficznych XXVIII/1

Huang, B. (2018) How Culture Influences Children Development, Boutmemouth University Retrieved June 2020.

Mbahi A. A. (2015). Design and Implementation. LENIAJ Publishers Maiduguri,

Muraino \& Ugwumba (2014). Teachers Perception on the Dimension of Moral Decadence. Retrieved 4/3/2019 from http://files.eric.edu.gov>

Njoku, M. (n.d). Nigerian Art: A Short Story. Retrived:17/06/21 from: affinityart.gallery/Nigerian-art-a-short-story-history/ 
Obi P. (2015). Youth development challenge. Retrieved 6/3/2019 from http://+.guardian.ng/features/youthspeak/youth-development-challenge/

Clawson, H. J. and Coolbaugh, J.T. (2000) The Youth Art Development Project, Justice Bulletin. Retrieved June, 2020)

Okafor, K. (2018). Nigerian Traditional Art and Culture. Retrieved: 17/06/21 from: legit.ng/1197521major-physical-features-nigeria.html

Okogba E. (2018). National Integration via Culture: children take front burner. Retrieved $4 / 3 / 2019$

From:https:/www.google.com/search?ei=b.inculcating + of + culture + in + the + nigerian + youth $+\& o q=$ incu lcating + of + culture + in + the + nigerian + youth $+\& g s \_1=$ mobile-gws-wiz-serp

Swap N. (2016). The Creativity and Academics: the power of arts education. Retrieved 4/3/2019 from http://www.edutopia.org/blog/creativity-academics-power-of-arts-education-niel-swapp https://www.legit.ng/1101506-nigerian-traditional-art-culture.html 